\title{
Associations of housing, management, milking activity, and standing and lying behavior of dairy cows milked in automatic systems
}

\author{
J. A. Deming, ${ }^{*}$ R. Bergeron, $†$ K. E. Leslie, $\ddagger$ and T. J. DeVries* ${ }^{* 1}$ \\ *Department of Animal and Poultry Science, University of Guelph, Kemptville Campus, 830 Prescott Street, Kemptville, ON, K0G 1J0, Canada \\ †Department of Animal and Poultry Science, University of Guelph, Alfred Campus, 31 St-Paul Street, PO Box 580, Alfred, ON, K0B 1A0, Canada \\ ‡Department of Population Medicine, University of Guelph, 50 Stone Road E., Guelph, ON, N1G 2W1, Canada
}

\begin{abstract}
The objective of this cross-sectional study was to describe the housing, feeding management, and characteristics (parity and stage of lactation) of cows on commercial automatic milking system (AMS) dairies and their associations with the standing and lying behavior patterns and milking activity (frequency and yield) of lactating dairy cows. Thirteen AMS herds were enrolled in the study, with an average herd size of $71 \pm$ 30 (mean \pm SD; range: 34 to 131) lactating cows. All of the herds used freestall barns, each set up for free cow traffic to the AMS. On-farm measurements were taken to determine stocking density at the freestalls $(0.9 \pm$ 0.1 cows/stall; mean $\pm \mathrm{SD})$, feed bunk $(0.66 \pm 0.17 \mathrm{~m}$ of feed bunk space/cow; mean $\pm \mathrm{SD}$ ), and AMS units $(55 \pm 11$ cows/AMS; mean $\pm \mathrm{SD})$. A random sample of 30 cows/herd was selected to monitor standing and lying behavior for $4 \mathrm{~d}$ using electronic data loggers. Times of feed delivery and feed push-up were recorded daily by the herd managers. Milking times, frequency, and yield were automatically recorded by the AMS units. Data were analyzed in a multivariable mixed regression model to determine which herd-level (housing and feeding management) and cow-level (parity, DIM, and milk yield) factors were associated with behavior and milking activity measures. Lying bout lengths were found to be negatively associated with milk yield and tended to be positively associated with more space at the feed bunk. Increased lying duration was associated with cows of lower milk production, increased space at the feed bunk, and increased frequency of feed pushup. Longer postmilking standing durations were associated with cows of higher parity. An association existed between cows milking less frequently when they were further in lactation, were of higher parity, and as stocking density at the AMS (cows/AMS) increased. Milk yield was positively associated with increased space at the feed bunk and higher parity and negatively associ-
\end{abstract}

Received July 26, 2012.

Accepted September 8, 2012.

${ }^{1}$ Corresponding author: tdevries@uoguelph.ca ated with DIM. From this study, it can be concluded that increased milking frequency may be achieved in AMS herds by reducing stocking density at the AMS unit. Further, in AMS systems, greater milk yield and lying duration may be achieved by ensuring that cows have ample feed bunk space and have their feed readily available to them in the bunk.

Key words: automatic milking, behavioral pattern, cross-sectional study, dairy cow

\section{INTRODUCTION}

The time budget of a lactating dairy cow housed in a freestall environment can be split into 7 main categories: milking, eating, lying/resting, ruminating, socializing in alleys, drinking, and standing in stalls (Grant and Albright, 2000). Poorly designed or mismanaged housing facilities can alter normal social interactions, interfere with lying behavior, and result in longer standing durations (Greenough and Vermunt, 1991; Singh et al., 1993; Bickert and Cermak, 1997). For instance, overcrowded barns (Wierenga and Hopster, 1990; Leonard et al., 1996; Fregonesi et al., 2007) and long waiting time for access to milking (Ketelaar de Lauwere et al., 1996; Gomez and Cook, 2010) have been demonstrated to affect the time cows have available for eating and lying behaviors. It has been found that cows housed intensively indoors express less synchronization of behavior than cows kept on pasture (Miller and Wood-Gush, 1991). However, in conventional dairy systems, synchronization of behavior does still occur, particularly around times of milking and feed delivery. For dairy herds with automated milking systems (AMS), the distribution of milking events is spread over a 24 -h period. Possibly as a result, less synchrony in the behavior of cows milked with AMS has been found in previous research (Winter and Hillerton, 1995).

In conventional systems, it is common for cows to leave the pen as a group to be milked and then to feed as a group upon their return from milking, particularly when fresh feed is available at the bunk (DeVries and von Keyserlingk, 2005). When cows are managed under 
the industry standard of $0.6 \mathrm{~m}$ of feed bunk space per cow, fewer than $70 \%$ of animals feed simultaneously at such peak times (DeVries et al., 2003). This suggests that space availability limits animals from feeding together, especially during popular eating times. If feeding space is limited, increased competition among cows at the feed bunk may lead to some cows modifying their feeding times to avoid aggressive interactions (Miller and Wood-Gush, 1991). When comparing parlor and AMS, Wagner-Storch and Palmer (2003) observed a more consistent flow of animals to the feed bunk in the AMS herds than in the conventional systems. These lower, more consistent percentages of cows eating at any one time could indicate that less linear feed bunk space per cow is required on AMS farms (Morita et al., 2000; Wagner-Storch and Palmer, 2003).

For group-housed and -fed dairy cows, the delivery of fresh feed is the most important factor in determining the feeding patterns (DeVries and von Keyserlingk, 2005). In fact, the more frequent the provision of fresh feed, the more time dairy cattle spend feeding throughout the day (DeVries et al., 2005). For AMS, the provision of fresh feed at multiple time points throughout the day may entice cattle to go feed and remain standing following milking rather than lie down. This approach would be beneficial for udder health (DeVries et al., 2010), as well as for improved cow traffic, resulting in greater milking frequency, more consistent milking intervals, and fewer fetched cows (Svennersten-Sjaunja and Pettersson, 2008).

In AMS, availability of the milking unit is of concern when trying to maximize milking frequencies, primarily because milking interval is known to have a significant effect on milk yield (Hogeveen et al., 2001). Cow-related factors, including milk yield, stage of lactation, and parity, are also known to affect milking frequency in AMS (Nixon et al., 2009). The success of AMS is likely largely affected by the combined result of effects of housing, management, and cow characteristics. Thus, the objective of this study was to describe the housing, feeding management, and characteristics of cows on commercial AMS dairies and their association with the standing and lying behavior patterns and milking activity (frequency and yield) of lactating dairy cows.

\section{MATERIALS AND METHODS}

\section{On-Farm Data Collection}

A cross-sectional observational study was performed on 13 AMS herds in Ontario (Canada) in July and August 2011. Of these herds, 10 milked with an Astronaut (Lely Industries N.V., Maassluis, the Netherlands), and 3 milked with a VMS (DeLaval International AB,
Tumba, Sweden). Herd sizes averaged $71 \pm 30$ (range: 34-131) lactating cows, and used either $1(\mathrm{n}=11)$ or 2 $(\mathrm{n}=2)$ AMS units. Dairy herds were selected randomly from a list of AMS herds situated within a geographical area wherein a large proportion of the AMS dairy herds in Ontario are located (southwestern Ontario). Herd owners were contacted by phone and asked about their willingness to participate in the study. The only criterion for enrollment was that the cows were housed in freestall barns set up for free cow traffic to the AMS. All herds had Holstein cows as the predominant breed, but this was not a criterion for selection.

A random sample of 30 cows per herd was selected to monitor standing and lying behavior and milking activity for 4 consecutive days. This method was based on previous research that demonstrated that reliable estimates of lying behavior on commercial dairy farms can be generated using $3 \mathrm{~d}$ of continuous recordings (at 1-min intervals) from 30 focal animals (Ito et al., 2009). During the 4 recording days, all successful milking events (including time, length, frequency, and yield) were automatically collected and electronically stored by the AMS. The focal cows were $144 \pm 92$ DIM and had an average parity of $2.3 \pm 1.2$ at the beginning of the data collection period. Data on cow parity and DIM were recorded from the AMS software. Standing and lying behaviors were collected using data loggers (HOBO Pendant G Data Logger; Onset Computer Corp., Pocasset, MA). This device measures leg orientation at 1-min intervals, and allows all the standing and lying behavior data to be collected electronically (Ledgerwood et al., 2010). Prior to use, care was taken to synchronize the times of the AMS and the data loggers. Data loggers were attached to one of the hind legs of the cows using veterinary bandaging tape (Vetrap Bandaging Tape; 3M Canada Co., London, ON, Canada) and recorded for the $4 \mathrm{~d}$. Data collected were used to calculate standing and lying durations ( $\mathrm{min} / \mathrm{d}$ ), bout frequency (no./d), and bout length ( $\mathrm{min} /$ bout). Postmilking standing duration (min) was calculated as the difference in time between the end of milking and the first recorded instance when the cow lay down following milking. Premilking standing duration (min) was calculated as the difference in time between the start of milking and the time at which the cow stood up before milking. During the $4 \mathrm{~d}$ of data collection, times of feed delivery and feed push-up were recorded by the various herd managers. These data were used to record frequencies of feed delivery and feed push-up.

On the initial visit to each herd, when data loggers were attached to the cows' legs, a survey was administered on farm where facility design and management were measured. On-farm measurements included stocking density at the feed bunk (m/cow), stalls (stalls/ 
cow), and AMS unit (cows/AMS). Style of feed bunk (flat surface or bunk) and feed barrier (post and rail or headlock bunk) were also recorded.

\section{Statistical Analysis}

Prior to analyses, all data were tested for normality using the UNIVARIATE procedure of SAS (SAS Institute, 2008). All data were summarized across each of the 4-d collection period for each cow. To determine the association of housing and management (frequency of fresh feed delivery, frequency of feed push-ups, type of feed bunk, and stocking density at the feed bunk, freestalls, and milking unit) and cow characteristics (parity and DIM) with milking (frequency and yield), standing, and lying behavior, a multivariable mixed model was fitted to the data using the MIXED procedure of SAS (SAS Institute, 2009). The models included the random effects of herd and cow within herd. Univariable analyses were conducted for the fixed effects of parity, DIM, milk yield, frequency of feed deliveries, frequency of feed push-ups, type of feed bunk, and stocking density at the feed bunk, freestalls, and AMS, on measures of standing and lying behavior and milking activity (frequency and milk yield) to determine which cow- and herd-level explanatory variables had an association with the outcome variable being evaluated. Only those variables with associations with $P<0.25$ in this initial screening were included in the multivariable linear regression model (Dohoo et al., 2009). The CORR procedure of SAS was used to check for correlations between the kept explanatory variables. If 2 variables were highly correlated $(\mathrm{r}>0.8)$, the one with the lower $P$-value in the univariable analysis was retained. Effects were considered significant at $P<0.05$ and tendencies at $P \leq 0.1$. Manual backward elimination of nonsignificant and nontrending effects were used and, from the resultant models, plausible 2 -way interactions were examined and retained if $P \leq 0.1$.

\section{RESULTS AND DISCUSSION}

Descriptive statistics for the study herds are found in Table 1. On average, study herds had low stocking density at the freestalls and slightly higher-than-recommended space availability at the feed bunk $(0.61 \mathrm{~m} / \mathrm{cow}$, Grant and Albright, 2001). A previous cross-sectional survey study found that the majority of freestall dairy herds, milking with parlors, in Minnesota provided 0.45 $\pm 0.11 \mathrm{~m}$ (range $=0.21$ to $0.75 \mathrm{~m}$ ) of feed bunk space per cow, well below industry recommendations (Endres and Espejo, 2010). Previous research has shown that lactating dairy cows experience less competition and improved access to feed when they are provided with more than the industry standard of $0.61 \mathrm{~m}$ of feed bunk space per animal (DeVries et al., 2004; DeVries and von Keyserlingk, 2006; Huzzey et al., 2006). Even though it has been suggested that feed bunk requirements for cows milked with an AMS may be less than the standard $0.61 \mathrm{~m} / \mathrm{cow}$ due to less synchronization of feeding activity (Morita et al., 2000; Wagner-Storch and Palmer, 2003), little research exists to support this recommendation. In fact, limited data exist on current feed bunk space availability on AMS herds. Thus, more research is needed in this area. It is widely accepted that having almost 60 cows/AMS unit is the optimal stocking density. In the current study, it was found that the average number of cows/AMS on the study herds was below this recommended standard (Table 1).

Across herds and the 4-d data collection period, $46 \%$ of the farms fed once daily, $38 \%$ fed twice daily, and $15 \%$ fed 3 times daily (Table 1). Castro et al. (2012) reported once-daily feeding frequencies in their observational study of 29 AMS herds. Bell et al. (2011) observed that AMS herds that fed with conventional feeding systems fed, on average, $1.4 \pm 1.0$ times/d and that those with automated feeding systems provided fresh feed $7.4 \pm$ 1.7 times/d. Even though little empirical data exist in that study or elsewhere to support this recommendation, Rodenburg (2002) suggested that providing fresh TMR several times per day (particularly in forced-cow traffic systems) could improve voluntary visits to the milking unit.

Four of the current study herds had fixed feed bunks where feed push-up was not necessary. Of the 9 remaining herds, 1 herd averaged 2 feed push-ups per day and 8 of the herds averaged more than 2 feed push-ups

Table 1. Descriptive statistics of feeding ${ }^{1}$ and housing ${ }^{2}$ management of 13 automated milking system (AMS) herds in Ontario, Canada

\begin{tabular}{lcccc}
\hline Variable & Mean & SD & Minimum & Maximum \\
\hline Frequency of feed delivery (no./d) & 1.6 & 0.8 & 1 & 3 \\
Frequency of feed push-up (no./d) & 2.1 & 1.6 & 0 & 5.5 \\
Stocking density at AMS (cows/AMS) & 55 & 11 & 34 & 71 \\
Stocking density at freestalls (cows/freestall) & 0.9 & 0.1 & 0.7 & 1.1 \\
Feed bunk space (m/cow) & 0.7 & 0.2 & 0.3 & 1.0 \\
\hline
\end{tabular}

${ }^{1}$ Feeding management data were collected over 4 consecutive days for each herd.

${ }^{2}$ Housing management data were taken on the first day of the data collection period on each farm. 
per day across their 4-d data collection period (Table 1). Limited observational data are available on the frequency of feed push-ups on AMS herds or recommendations for such frequencies. In a survey study of conventionally milked freestall herds in Minnesota, Endres and Espejo (2010) observed an average of $5.4 \pm$ 2.3 feed push-ups daily.

Limited data exist on duration of resting behavior of cows kept in AMS herds. In the current study, lying duration (Table 2) was similar to that observed by DeVries et al. (2011) in an AMS herd, where they reported lying duration of $11.2 \pm 2.5 \mathrm{~h} / \mathrm{d}$. Cows in the current study, who did not have to stand waiting in a conventional restricted holding area before milking, had similar lying durations to reports of cows in parlormilking, freestall systems (Wechsler et al., 2000; Cook et al., 2005; Ito et al., 2009). In conventional parlormilking, freestall systems, cows are restricted to a holding area before milking. The cows in the current study were not subjected to a restricted holding area, but nevertheless had similar lying durations, although we hypothesized they would have longer lying durations. Although data on the AMS waiting area (open area in front of the milking stall) were not collected in the current study, Jacobs et al. (2012) reported multiple factors concerning the waiting area that cause cows to hesitate to enter the AMS and may cause cows to stand waiting for longer periods of time to access the AMS. It is possible that the AMS waiting area has a similar effect on the standing duration of the cows as parlor holding pens in conventional systems.

Lying bout frequencies and lengths are also found in Table 2. Average bout frequency and duration in the current study were similar to what DeVries et al. (2011) observed in an AMS herd $(8.0 \pm 2.9$ bouts/d; $84.1 \pm$ $38.4 \mathrm{~min}$ in length). There is a shortage of data on the average duration of lying bouts and bout frequencies of cows in AMS herds.
Similar to that previously observed in AMS milked cows by DeVries et al. (2011), cows in the current study with greater milk yields had shorter lying bouts and shorter overall lying durations (Table 3). This supports the notion that cows with greater milk yields have higher energy requirements than lesser-yielding cows, requiring them to attend the feed bunk more often (Bewley et al., 2010; DeVries et al., 2011). Lying duration was positively associated with greater frequency of feed push-ups as well as increased space at the feed bunk. Researchers have previously indicated that increased frequency of feed push-ups has little effect on feed bunk attendance and less effect on feeding activity than delivery of fresh feed (DeVries et al., 2003). However, it is possible that with feed being pushed up more frequently, feed is more readily available in the bunk (Endres and Espejo, 2010). Additionally, it has been demonstrated that when more space is available to cows at the feed bunk, they can dedicate more time to eating. Furthermore, this may result in cows eating in a more efficient manner (with less inactive standing in the feeding area; DeVries and von Keyserlingk, 2006), and being able to direct more of their time to lying down (DeVries et al., 2005). Additionally, with more feed bunk space, cows may encounter fewer animals at the feed bunk and, therefore, be subjected to fewer aggressive interactions (DeVries and von Keyserlingk, 2006). Further studies in which feeding behavior is measured would be needed to confirm this hypothesis. This also may be the reason why lying bout duration was positively associated with increased space at the feed bunk. It is interesting to note that the majority of the herds enrolled on this study were understocked at the feed bunk. It is possible that barns that had ample space allowances at the feed bunk were built with the intention of future expansion that they had not yet achieved. Alternatively, it is possible that herds that had old barns that had been converted to accommodate an AMS that were originally

Table 2. Descriptive statistics of the cow, milking activity, and behavior variables collected for 30 cows/herd in 13 automated milking system (AMS) herds in Ontario, Canada ${ }^{1}$

\begin{tabular}{lcccc}
\hline Variable & Mean & SD & Minimum & Maximum \\
\hline Parity & 2.3 & 0.5 & 1.4 & 3.2 \\
DIM $^{2}$ & 144 & 34 & 93 & 209 \\
Milking frequency (no./d) & 2.8 & 0.4 & 2.3 & 9.8 \\
Milk yield (kg/d) & 35.1 & 10 & 9.3 & 68 \\
Lying duration (h/d) & 10.8 & 1.2 & 2.3 & 13.9 \\
Lying bouts (no./d) & 9.3 & 3.1 & 29.1 & 25.8 \\
Lying bout length (min/bout) & 78.1 & 28.2 & 34 & 110.9 \\
Postmilking standing duration (min) & 75 & 20 & 52 & 185.8 \\
Premilking standing duration (min) & 103.4 & 35.5 & & 10 \\
\hline
\end{tabular}

${ }^{1}$ Milking activity and behavior data collected over a 4-consecutive-day observation period per cow.

${ }^{2}$ Days in milk at the beginning of each observation period. 
designed for fewer animals and, thus, had higher space allowances at the feed bunk.

Average premilking and postmilking standing durations are found in Table 2. Average postmilking standing duration in the current study (75 min) was longer than that previously reported for conventionally milked, freestall-housed cows (35 min: Tyler et al., 1997; 55 min: DeVries and von Keyserlingk, 2005; 62 min: DeVries et al., 2005). The findings from our study were similar to that reported for an AMS study and also cows housed and milked in tiestalls (78.4 min; DeVries et al., 2011; 79 min; DeVries et al., 2010).

Previous research has indicated that it is beneficial for cows to remain standing after milking to help prevent IMI (Peeler et al., 2000). The reason for this approach is that keeping cows standing after milking is thought to allow time for the teat canal to close, limiting the chance of bacteria penetrating the teat and infecting the udder should the cow lie down in a soiled stall (McDonald, 1975; Schultze and Bright, 1983). Conversely, it has also been shown that cows that remain standing for over $1.5 \mathrm{~h}$ after milking in a tiestall system, and over $2.5 \mathrm{~h}$ in a freestall AMS system, also have an increased risk of a new udder infection caused by environmental bacteria (DeVries et al., 2010, 2011). It has been hypothesized that a second period of increased teat canal diameter occurs (following the initial period that occurs immediately after milking) and, thus, bacterial penetrability, occurring approximately $2 \mathrm{~h}$ following milking (McDonald, 1975; Schultze and Bright, 1983). In a previous AMS study, postmilking standing duration increased when cows milked close in time to a feed delivery or feed push-up (DeVries et al., 2011), suggesting that frequent feed delivery and push-up may increase postmilking standing duration. However, in the current study, postmilking standing behavior was not found to be associated with frequency of feed delivery. Premilking standing duration was negatively associated with frequency of feed push-ups (Table 3). This may, again, relate to the hypothesis that if feed is more available to the cows with increased frequency of feed push-ups, they may choose to lie down rather than actively search for food. Postmilking standing duration was associated with parity (Table 3); cows of greater parity spent more time standing following milking. To our knowledge, this may be the first report of such an association. It is possible that older cows likely produce more milk, have higher metabolic demands, and thus remain standing to eat more. In our model, however, milk yield was not a predictor of postmilking standing duration. This would suggest, therefore, that there is likely another factor influencing this phenomenon that we have not captured. Hence, more research is needed to address this finding.

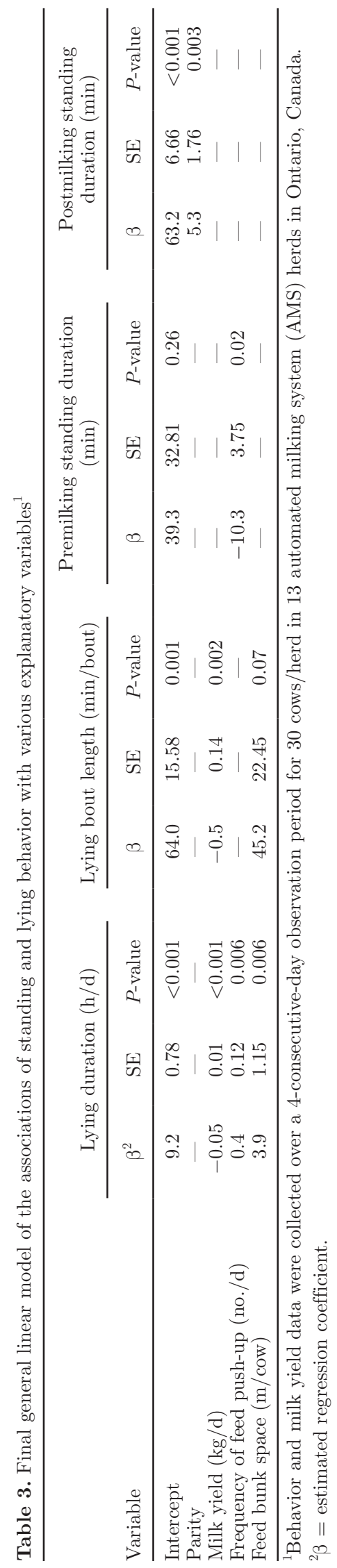


Milk yield data can be found in Table 2. An observational study by Castro et al. (2012) observed an average of $28.5 \pm 3.9 \mathrm{~kg} / \mathrm{d}$ for AMS cows in free-cow traffic systems. Cows in the current study had greater milk yield when provided more space at the feed bunk (Table 4). Very few studies exist in both conventional and AMS systems concerning feed bunk space availability and milk production. Næss et al. (2011) reported that no evidence exists that feed bunk space has any significant effect on milk yield in both conventional parlor systems and AMS. It has been documented that reducing feed bunk space has a negative effect on feeding behavior for freestall-housed cows milked in conventional parlors (Friend et al., 1977; DeVries et al., 2004), most notably affecting low-ranked cows (Huzzey et al., 2006). Evidence exists supporting DMI being positively correlated with milk yield in conventional milking systems (Martin and Sauvant, 2002). It follows that formulating rations with appropriate DMI for AMS-milked cows is of importance, which has been noted by Halachmi et al. (2011). It is possible that more space at the feed bunk resulted in higher milk yields because cows may be encountering fewer aggressive interactions at the feed bunk and having the chance to increase DMI (DeVries and von Keyserlingk, 2006). However, it should be noted that herd-level and cow-level DMI and aggressive interactions were not recorded in this study.

Across herds, cows averaged $2.8 \pm 0.4$ milkings $/ \mathrm{d}$ (mean \pm SD; Table 2). Compared with other studies and reports of milking frequencies in AMS, this observed milking frequency was high. The closest observed milking frequency was an observational study of free-cow traffic AMS herds in which Castro et al. (2012) observed an average of $2.7 \pm 0.3$ milkings/d. Another observational study reported an average of 2.5 milkings/d for free-cow traffic AMS units (Gygax et al., 2007). Other nonobservational studies have reported milking frequencies ranging from 2.2 to 2.5 milkings/d (Wagner-Storch and Palmer, 2003; Bach et al., 2009). However, Madsen et al. (2010) reported 3.0 milkings/d in a free-cow traffic system, indicating that a greater cow throughput of the AMS is possible. Interestingly, researchers have previously reported greater milking frequency with forced-traffic (2.5 to 2.9 milkings/d) compared with free-traffic systems (2.0 to 2.2 milkings/d; Melin et al., 2007; Bach et al., 2009). All of the herds enrolled in this current study used free-traffic systems and still had relatively high milking frequencies.

Cows had greater milking frequency when there was lower stocking density at the AMS unit (Table 4). Availability of the AMS is an important factor when trying to maximize milking frequencies (Hogeveen et al., 2001). Jacobs et al. (2012) found that even in understocked AMS herds, cow behavior and group dynamics may influence the availability, efficiency, and overall success of the AMS. Additionally, those researchers speculated that when the AMS is at full capacity, the largest influence on AMS time budgets could be social dynamics within groups of cows or individual variation in behavior. In robotic systems, it is recommended that cows frequent the AMS as much as possible to optimize successful milking visits. Similarly to findings observed by Gygax et al. (2007), cows in this study had a higher milking frequency in early lactation than cows later in lactation. This result, coupled with our finding of an association of decreased milk yield with increased DIM, may suggest that visits to the AMS closely reflect the change in milk yield throughout lactation. Also in agreement with previous research by Bach et al. (2009), cows of greater parity had fewer milkings per day. Work by Spolders et al. (2004) supports the findings from the current study that multiparous cows visit the AMS less frequently than primiparous cows, and that milk yield is higher for multiparous cows. The authors encourage more research to better understand the association of greater parity and fewer milkings in AMS.

\section{CONCLUSIONS}

In this observational study, we found that cows milked in free-cow traffic AMS herds in Ontario milked more frequently when they were of lower parity, were

Table 4. Final general linear model of the associations of milking activity ${ }^{1}$ with various explanatory variables

\begin{tabular}{|c|c|c|c|c|c|c|}
\hline Variable & \multicolumn{3}{|c|}{ Milk yield (kg/d) } & \multicolumn{3}{|c|}{ Milkings (no./d) } \\
\hline Intercept & 26.6 & 3.70 & $<0.001$ & 4.4 & 0.51 & $<0.001$ \\
\hline Parity & 1.9 & 0.031 & $<0.001$ & -0.06 & 0.028 & 0.05 \\
\hline Cows/AMS unit & - & - & - & -0.02 & 0.0088 & 0.04 \\
\hline Feed bunk space (m/cow) & 16.9 & 5.32 & 0.01 & - & - & - \\
\hline
\end{tabular}

\footnotetext{
${ }^{1}$ Milking activity data collected over a 4-consecutive-day observation period for 30 cows/herd in 13 automated milking system (AMS) herds in Ontario, Canada.

${ }^{2} \beta=$ estimated regression coefficient.

${ }^{3}$ Days in milk at the beginning of each observation period.
} 
of fewer DIM, and experienced lower stocking density at the AMS. Overall, daily lying duration in these cows was positively associated with providing more space at the feed bunk and increased frequency of feed push-ups. Additionally, we found that cows had greater milk yield when provided with greater space at the feed bunk. From this study, it can be concluded that increased milking frequency may be achieved on AMS herds by reducing the number of cows per automated milking unit. Further, in AMS systems, greater milk yield and lying duration may be achieved by ensuring that cows have ample feed bunk space and have their feed readily available to them in the bunk. Further studies concerning feed bunk space allowance and feed intake of both subordinate and dominant animals would be useful to help explain some of the found associations.

\section{ACKNOWLEDGMENTS}

We thank the participating farms for the use of their animals and facilities. We thank Julie Fish, Jessica Zaffino, Clemence Nash, and Candace Zettler of the University of Guelph (Guelph, ON, Canada) for their technical assistance through the data collection periods. Additionally, we thank Tony Brazda (Lely Canada Inc., Woodstock, ON, Canada) for his assistance in contacting the farms in the study area. This research was funded through the Ontario Ministry of Agriculture, Food and Rural Affairs (OMAFRA; Guelph, ON, Canada) New Directions Research Program. This research was also financed in part by the Natural Science and Engineering Research Council of Canada (Ottawa, ON, Canada); Alberta Milk (Edmonton, AB, Canada); Dairy Farmers of New Brunswick (Sussex, NB, Canada), Nova Scotia (Lower Truro, NS, Canada), Ontario (Mississauga, ON, Canada), and Prince Edward Island (Charlottetown, PE, Canada); Novalait Inc. (Québec, QC, Canada); Dairy Farmers of Canada (Ottawa, ON, Canada); Canadian Dairy Network (Guelph, ON, Canada); Agriculture and Agri-Food Canada (Ottawa, ON, Canada); Public Health Agency of Canada (Ottawa, ON, Canada); Technology Prince Edward Island Inc. (Charlottetown, PE, Canada); Université de Montréal (Montréal, QC, Canada); and the University of Prince Edward Island (Charlottetown, PE, Canada), through collaboration with the Canadian Bovine Mastitis Research Network (Saint-Hyacinthe, QC, Canada). This research was also supported through contributions from the Canadian Foundation for Innovation (Ottawa, ON, Canada) and the Ontario Research Fund (Toronto, ON, Canada).

\section{REFERENCES}

Bach, A., M. Devant, C. Igleasias, and A. Ferrer. 2009. Forced traffic in automatic milking systems effectively reduces the need to get cows, but alters eating behavior and does not improve milk yield of dairy cattle. J. Dairy Sci. 92:1272-1280.

Bell, Z., G. Andre, and J. C. A. M. Pompe. 2011. Effect of automatic feeding of total mixed rations on the diurnal visiting pattern of dairy cows to an automatic milking system. Biosystems Eng. 111:33-39.

Bewley, J. M., R. E. Boyce, J. Hockin, L. Munksgaard, S. D. Eicher, and M. E. Einstein. 2010. Influence of milk yield, stage of lactation and body condition on dairy cattle lying behavior using an automated activity monitoring sensor. J. Dairy Res. 77:1-6.

Bickert, W. G., and J. Cermak. 1997. Housing considerations relevant to lameness of dairy cows. Pages 300-307 in Lameness of Cattle. 3rd ed. W. B. Saunders Co., Philadelphia, PA.

Castro, A., J. M. Pereira, C. Amiama, and J. Bueno. 2012. Estimating efficiency in automatic milking systems. J. Dairy Sci. 95:929-936.

Cook, N. B., T. B. Bennett, and K. V. Nordlund. 2005. Monitoring indices of cow comfort in free-stall-housed dairy herds. J. Dairy Sci. 88:3876-3885.

DeVries, T. J., J. A. Deming, J. Rodenburg, G. Seguin, K. E. Leslie, and H. W. Barkema. 2011. Association of standing and lying behavior patterns and incidence of intramammary infection in dairy cows milked with an automatic milking system. J. Dairy Sci. 94:3845-3855

DeVries, T. J., S. Dufour, and D. T. Scholl. 2010. Relationship between feeding strategy, lying behavior patterns, and incidence of intramammary infection in dairy cows. J. Dairy Sci. 93:1987-1997.

DeVries, T. J., and M. A. G. von Keyserlingk. 2005. Time of feed delivery affects the feeding and lying patterns of dairy cows. J. Dairy Sci. 88:625-631.

DeVries, T. J., and M. A. G. von Keyserlingk. 2006. Feed stalls affect the social and feeding behavior of lactating dairy cows. J. Dairy Sci. 89:3522-3531.

DeVries, T. J., M. A. G. von Keyserlingk, and K. A. Beauchemin. 2003. Diurnal feeding pattern of lactating dairy cows. J. Dairy Sci. 86:4079-4082.

DeVries, T. J., M. A. G. Von Keyserlingk, and K. A. Beauchemin. 2005. Frequency of feed delivery affects the behavior of lactating dairy cows. J. Dairy Sci. 88:3553-3562.

DeVries, T. J., M. A. G. von Keyserlingk, and D. M. Weary. 2004. Effect of feeding space on the inter-cow distance, aggression, and feeding behavior of free-stall housed lactating dairy cows. J. Dairy Sci. 87:1432-1438.

Dohoo, I., W. Martin, and H. Stryhn. 2009. Veterinary Epidemiologic Research. VER Inc., Charlottetown, Prince Edward Island, Canada.

Endres, M. I., and L. A. Espejo. 2010. Feeding management and characteristics of rations for high-producing dairy cows in freestall herds. J. Dairy Sci. 93:822-829.

Fregonesi, J. A., C. B. Tucker, and D. M. Weary. 2007. Overstocking reduces lying time in dairy cows. J. Dairy Sci. 90:3349-3354.

Friend, T. H., C. E. Polan, and M. L. McGilliard. 1977. Free stall and feed bunk requirements relative to behavior, production and individual feed intake in dairy cows. J. Dairy Sci. 60:108-116.

Gomez, A., and N. B. Cook. 2010. Time budgets of lactating dairy cattle in commercial freestall herds. J. Dairy Sci. 93:5772-5781.

Grant, R. J., and J. L. Albright. 2000. Feeding behavior. Pages 365382 in Farm Animal Metabolism and Nutrition. J. P. F. D'Mello, ed. CABI Publishing, Wallingford, Oxon, UK.

Grant, R. J., and J. L. Albright. 2001. Effect of animal grouping on feeding behavior and intake of dairy cattle. J. Dairy Sci. 84(E. Suppl.):E156-E163.

Greenough, P. R., and J. J. Vermunt. 1991. Evaluation of subclinical laminitis in a dairy herd and observations on associated nutritional and management factors. Vet. Rec. 128:11-17.

Gygax, L., I. Neuffer, C. Kaufmann, R. Hauser, and B. Wechsler. 2007. Comparison of functional aspects in two automatic milking systems and auto-tandem milking parlors. J. Dairy Sci. 90:42654274 .

Halachmi, I., C. F. Børsting, E. Maltz, Y. Edan, and M. R. Weisbjerg. 2011. Feed intake of Holstein, Danish Red, and Jersey cows in automatic milking systems. Livest. Sci. 138:56-61. 
Hogeveen, H., W. Ouweltjes, C. J. A. M. de Koning, and K. Stelwagen. 2001. Milking interval, milk production and milk flow-rate in an automatic milking system. Livest. Prod. Sci. 72:157-167.

Huzzey, J. M., T. J. DeVries, P. Valois, and M. A. G. von Keyserlingk. 2006. Stocking density and feed barrier design affect the feeding and social behavior of dairy cattle. J. Dairy Sci. 89:126-133.

Ito, K., D. M. Weary, and M. A. G. von Keyserlingk. 2009. Lying behavior: Assessing within- and between-herd variation in free-stallhoused dairy cows. J. Dairy Sci. 92:4412-4420.

Jacobs, J. A., K. Ananyeva, and J. M. Siegford. 2012. Dairy cow behavior affects the availability of an automatic milking system. J. Dairy Sci. 95:2186-2194.

Ketelaar-de Lauwere, C. C., S. Devir, and J. H. M. Metz. 1996. The influence of social hierarchy on the time budget of cows and their visits to an automatic milking system. Appl. Anim. Behav. Sci. 49:199-211.

Ledgerwood, D. N., C. Winckler, and C. B. Tucker. 2010. Evaluation of data loggers, sampling intervals, and editing techniques for measuring the lying behavior of dairy cattle. J. Dairy Sci. 93:5129-5139.

Leonard, F. C., J. M. O'Connell, and K. J. O'Farrell. 1996. Effect of overcrowding on claw health in first-calved Friesian heifers. Br. Vet. J. 152:459-472.

Madsen, J., M. R. Weisbjerg, and T. Hvelplund. 2010. Concentrate composition for automatic milking systems - Effect on milking frequency. Livest. Sci. 127:45-50.

Martin, O., and D. Sauvant. 2002. Metaanalysis of input/output kinetics in lactating dairy cows. J. Dairy Sci. 85:3363-3381.

McDonald, J. S. 1975. Radiographic method for anatomic study of the teat canal: Changes between milking periods. Am. J. Vet. Res. 36:1241-1242.

Melin, M., G. Pettersson, K. Svennersten-Sjaunja, and H. Wiktorsson. 2007. The effects of restricted feed access and social rank on feeding behavior, ruminating and intake for cows managed in automated milking systems. Appl. Anim. Behav. Sci. 107:13-21.

Miller, K., and D. G. M. Wood-Gush. 1991. Some effects of housing on the social behaviour of dairy cows. Anim. Prod. 53:271-278.

Morita, S., E. Nirasawa, S. Sugita, S. Hoshiba, M. Tokida, H. Hirayama, and K. Uetake. 2000. Cow behaviour and working time of a stockperson in a free-stall barn with an automatic milkingfeeding system. In Robotic Milking-Proc. Int. Symp., Lelystad, the Netherlands. H. Hogeveen and A. Meijering, ed. Wageningen Pers, Wageningen, the Netherlands.

Næss, G., K. E. Bøe, and O. Østerås. 2011. Layouts for small freestall dairy barns: Effect on milk yield for cows in different parities. J. Dairy Sci. 94:1256-1264.
Nixon, M., J. Bohmanova, J. Jamrozik, L. R. Schaeffer, K. Hand, and F. Miglior. 2009. Genetic parameters of milking frequency and milk production traits in Canadian Holsteins milked by an automated milking system. J. Dairy Sci. 92:3422-3430.

Peeler, E. J., M. J. Green, J. L. Fitzpatrick, K. L. Morgan, and L. E. Green. 2000. Risk factors associated with clinical mastitis in low somatic cell count British dairy herds. J. Dairy Sci. 83:2464-2472.

Rodenburg, J. 2002. Robotic milkers: What, where . . . and how much!!?? Pages 1-18 in Proc. Ohio Dairy Management Conference. The Ohio State University, Columbus.

SAS Institute. 2008. SAS 9.1 User's Guide. SAS Institute Inc., Cary, NC.

SAS Institute. 2009. SAS 9.2. User's Guide. SAS Institute Inc., Cary, $\mathrm{NC}$

Schultze, W. D., and S. C. Bright. 1983. Changes in penetrability of bovine papillary duct to endotoxin after milking. Am. J. Vet. Res. 44:2373-2375.

Singh, S. S., W. R. Ward, K. Lautenbach, J. W. Hughes, and R. D. Murray. 1993. Behavior of first lactation and adult dairy cows while housed and at pasture and its relationship with sole lesions. Vet. Rec. 133:469-474.

Spolders, M., U. Meyer, G. Flachowsky, and M. Coenen. 2004. Differences between primiparous and multiparous cows in voluntary milking frequency in an automatic milking system. Ital. J. Anim. Sci. 3:167-175.

Svennersten-Sjaunja, K. M., and G. Pettersson. 2008. Pros and cons of automatic milking in Europe. J. Anim. Sci. 86:37-46.

Tyler, J. W., L. K. Fox, S. M. Parish, J. Swain, D. L. Johnson, H. A. Grasseschi, and R. Gant. 1997. Effect of feed availability on postmilking standing time in dairy cows. J. Dairy Res. 64:617-620.

Wagner-Storch, A. M., and R. W. Palmer. 2003. Feeding behavior, milking behavior, and milk yields of cows milked in a parlor versus an automatic milking system. J. Dairy Sci. 86:1494-1502.

Wechsler, B., J. Schaub, K. Friedli, and R. Hauser. 2000. Behaviour and leg injuries in dairy cows kept in cubicle systems with straw bedding or soft lying mats. Appl. Anim. Behav. Sci. 69:189-197.

Wierenga, H. K., and H. Hopster. 1990. The significance of cubicles for behaviour of dairy cows. Appl. Anim. Behav. Sci. 26:309-337.

Winter, A., and J. E. Hillerton. 1995. Behaviour associated with feeding and milking of early lactation cows housed in an experimental automatic milking system. Appl. Anim. Behav. Sci. 46:1-15. 